\title{
WYBRANE ZAGADNIENIA FIZYKOCHEMII KOLOIDÓW W PROCESACH INHALACYJNEGO DOSTARCZANIA LEKÓW DO PLUC
}

SELECTED PROBLEMS OF THE PHYSICAL CHEMISTRY OF COLLOIDS IN DRUG DELIVERY TO THE LUNGS BY INHALATION

\section{Tomasz R. Sosnowski*, Katarzyna Dobrowolska}

Wydziat Inżynierii Chemicznej i Procesowej Politechniki Warszawskiej,

ul. Waryńskiego 1,

00-645 Warszawa

*e-mail: Tomasz.Sosnowski@pw.edu.pl 


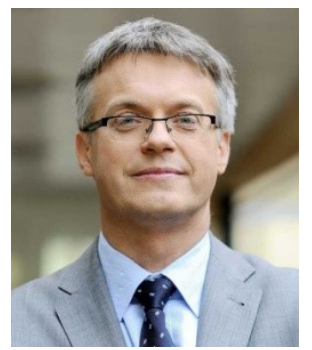

Prof. dr hab. inż. Tomasz Sosnowski jest kierownikiem Katedry Inżynierii i Procesów Zintegrowanych i Prodziekanem ds. Nauki na Wydziale Inżynierii Chemicznej i Procesowej Politechniki Warszawskiej. Jednocześnie pełni funkcję przewodniczącego Rady Naukowej Dyscypliny „Inżynieria Chemiczna” na PW oraz jest członkiem (z wyboru) Komitetu Inżynierii Chemicznej i Procesowej PAN. W badaniach naukowych koncentruje się na analizie procesów przenoszenia pędu i masy w układach rozproszonych, w szczególności dotyczących aerozoli $\mathrm{i}$ ich fizykochemicznego oddziaływania $\mathrm{z}$ układem oddechowym. Istotna część dorobku badawczego dotyczy zjawisk przebiegających w układzie surfaktantu płucnego (tematyka doktoratu w 1997, poszerzona w habilitacji w 2006). W latach 1999-2000 odbył staż podoktorski $\mathrm{w}$ Lovelace Respiratory Research Institute (Albuquerque, USA), który zaowocował rozwojem tematyki związanej z inhalacyjnym dostarczaniem leków, prowadzonej we współpracy z pulmonologami. Autor ponad 90 publikacji w czasopismach JCR, cytowanych ponad 960 razy $(\mathrm{h}=18)$.

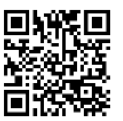

https://orcid.org/0000-0002-6775-3766

Mgr inż. Katarzyna Dobrowolska obecnie jest związana z Wydziałem Inżynierii Chemicznej i Procesowej Politechniki Warszawskiej, na którym w 2017 r. rozpoczęła studia doktoranckie na kierunku inżynieria chemiczna. W 2015 r. uzyskała tytuł inżyniera na kierunku Biotechnologia, a w 2017 r. tytuł magistra na specjalności Biotechnologia Przemysłowa. Jej zainteresowania naukowe związane są z analizą depozycji cząstek aerozoli w układzie oddechowym oraz ich wpływu na powierzchnię płucną.

https://orcid.org/0000-0003-1859-5455 


\begin{abstract}
The paper highlights selected problems of physical chemistry and dynamics of colloidal systems indispensable for the understanding and optimization of drug delivery by inhalation. Besides describing the fundamental aspects of aerosol flow and deposition in the respiratory system, some problems related to particle or droplet generation in the inhalers are discussed. In particular, the influence of liquid properties on aerosol formation in different nebulizers is demonstrated as a critical factor in successful aerosol therapy. The paper also addresses interactions between inhaled drug particles and bronchial mucus or the pulmonary surfactant, indicating another broad field of colloid and interface science application in medicine.
\end{abstract}

Keywords: colloidal systems, aerosols, drug delivery, inhalation, lung surface Słowa kluczowe: układy koloidalne, aerozole, dostarczanie leków, inhalacja, powierzchnia płuc 


\section{WYKAZ STOSOWANYCH SKRÓTÓW}

ALI

DPI

DPPC

NAC

pMDI

POChP

RV

SMI

SP

UO

$\Delta P$

$Q$

$R_{D}$

$\sigma$

$\nabla \sigma$
- powierzchnia międzyfazowa ciecz-powietrze (air-liquid interface)

- inhalator proszkowy (dry powder inhaler)

- dipalmitylofosfatydylocholina

- n-acetylocysteina

- inhalator ciśnieniowy (pressurized metered dose inhaler)

- przewlekła obturacyjna choroba płuc

- objętość rezydualna nebulizatora (residual volume)

- inhalator miękkiej mgły (soft mist inhaler)

- surfaktant płucny

- układ oddechowy

- spadek ciśnienia w inhalatorze DPI

- strumień objętościowy (przepływ) powietrza

- współczynnik wewnętrznego oporu aerodynamicznego inhalatora DPI

- napięcie powierzchniowe

- gradient napięcia powierzchniowego 


\section{WPROWADZENIE}

Schorzenia dróg oddechowych (np. astma, POChP, pylica i inne schorzenia restrykcyjne) są zaliczane do chorób cywilizacyjnych, których częstość występowania nasila się wraz ze wzrostem zanieczyszczenia powietrza przez pyły i substancje gazowe [1]. Oddychanie, będące podstawowym procesem życiowym, wymaga poboru przez organizm do $10 \mathrm{~m}^{3}$ powietrza w ciągu doby. Wraz $\mathrm{z}$ wdychanym powietrzem do płuc przedostają się zawieszone $\mathrm{w}$ nim cząstki aerozolowe, które z rożną sprawnością osadzają się (ulegają depozycji) na powierzchni układu oddechowego (w skrócie: UO). Dane ilościowe na temat przepływu i dystrybucji wdychanych cząstek w obrębie poszczególnych struktur drzewa oskrzelowego, które mogą dostarczyć cennych informacji na temat ich potencjalnej toksyczności, są skutecznie pozyskiwane dzięki opisowi fizykochemii aerozolowych układów koloidalnych, tj. dyspersji mikronowych i submikronowych cząstek lub kropel zawieszonych w powietrzu. Ta elementarna wiedza, postrzegana jako mniej ważna przed 2020 r., nabrała dodatkowego znaczenia w dobie pandemii COVID-19 jako choroby transmitowanej głównie drogą kropelkową [2].

Warto zauważyć, że po depozycji cząstek w płucach, tj. gdy kontaktują się one z cieczami pokrywającymi nabłonek UO, które zawierają śluz oskrzelowy lub surfaktant płucny, także ważną rolę odgrywają zjawiska biegnące w układach koloidalnych - tym razem ciekłych, zawierających naturalne substancje o szczególnych właściwościach reologicznych i powierzchniowo-czynnych [3].

Choroby płuc, które często są wywołane przez wdychanie szkodliwych aerozoli, mogą być leczone dzięki wprowadzeniu leków tą samą drogą, tj. przez inhalację cząstek lub kropel, zawierających substancje lecznicze. Taka metoda dostarczania farmaceutyków jest znana jako aerozoloterapia i stanowi podstawowy sposób leczenia pacjentów $\mathrm{z}$ różnych grup wiekowych, o różnym podłożu i przebiegu chorób płuc [4]. Zapewnienie skutecznej aerozoloterapii, na którą składa się powtarzalne wytworzenie zdefiniowanej dawki aerozolu o określonej charakterystyce (m.in. odpowiedniej wielkości cząstek), a następnie jej wprowadzenie do określonych przestrzeni UO, również wymaga istotnego wkładu wiedzy z zakresu fizyki układów aerozolowych.

Niniejszą pracę poświęcono wybranym wyzwaniom, wobec których staje współczesna aerozoloterapia i z którymi - czasem w większym stopniu niż lekarze muszą zmierzyć się inżynierowie i naukowcy specjalizujący się w fizykochemii układów koloidalnych. 


\section{PODSTAWY FIZYKOCHEMICZNE AEROZOLOTERAPII}

Określenie przestrzennego rozkładu depozycji cząstek w UO wymaga dokładnej znajomości jego budowy (struktury), charakteru przepływu wdychanego aerozolu oraz właściwości cząstek lub kropel zawieszonych we wdychanym powietrzu. Dostępne dane morfometryczne płuc (modele m.in. Weibela, Cumminsa, Yeh-Schuma, i inne [5]) pozwalają określić chwilową prędkość powietrza/aerozolu w nosie, ustach, gardle, tchawicy lub dowolnej gałęzi drzewa oskrzelowego. Warunki przepływu powietrza wewnątrz UO ewoluują ze względu na zmienność jego struktury geometrycznej, począwszy od nosa lub jamy ustnej i gardła, poprzez tchawicę i rozgałęziającą się strukturę drzewa oskrzelowego (oskrzela, oskrzeliki, oskrzeliki oddechowe i końcowe), aż po pęcherzyki płucne, Rys.1. Dysponując danymi na temat przepływu aerozolu w drogach oddechowych, można dla dowolnego zakresu rozmiaru wdychanych cząstek określić dominujące mechanizmy depozycji w konkretnych strukturach UO. Cząstki osadzają się w wyniku działania podstawowych mechanizmów: bezwładności, sedymentacji i dyfuzji (Rys.2), których efektywność zależy od wielkości cząstek i ich czasu przebywania w danym elemencie UO.

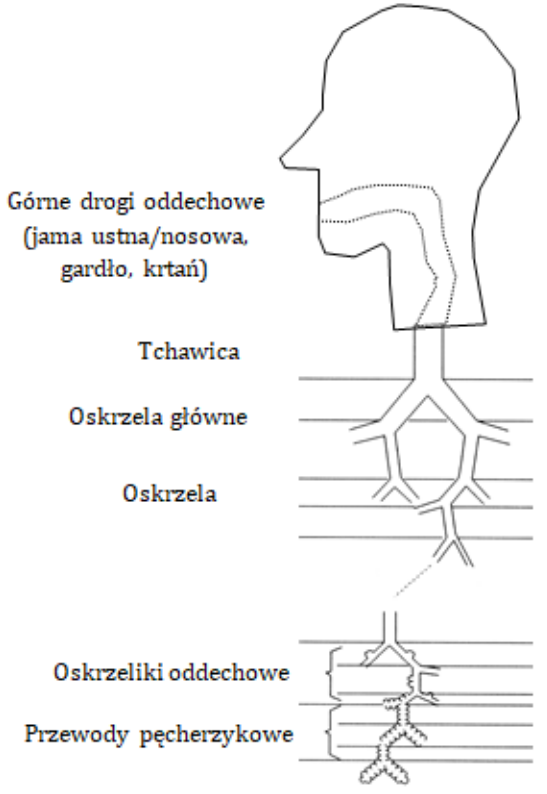

Woreczki pecherzykowe

Rysunek 1. Schemat struktury układu oddechowego człowieka (na podstawie [5])

Figure 1. Schematic structure of the respiratory system (based on [5]) 
$\mathrm{Na} \quad$ Rys. 3 przedstawiono schematycznie sprawność depozycji w poszczególnych strukturach układu oddechowego w funkcji średnicy cząstek. Analiza możliwości penetracji aerozolu do poszczególnych struktur drzewa oskrzelowego i ich lokalnej sprawności depozycji pozwala stwierdzić, że z punktu widzenia dostarczania leków dla celów aerozoloterapii najbardziej pożądane są cząstki mniejsze od $5 \mu \mathrm{m}$, zwane cząstkami drobnymi (fine particles) [6,7].

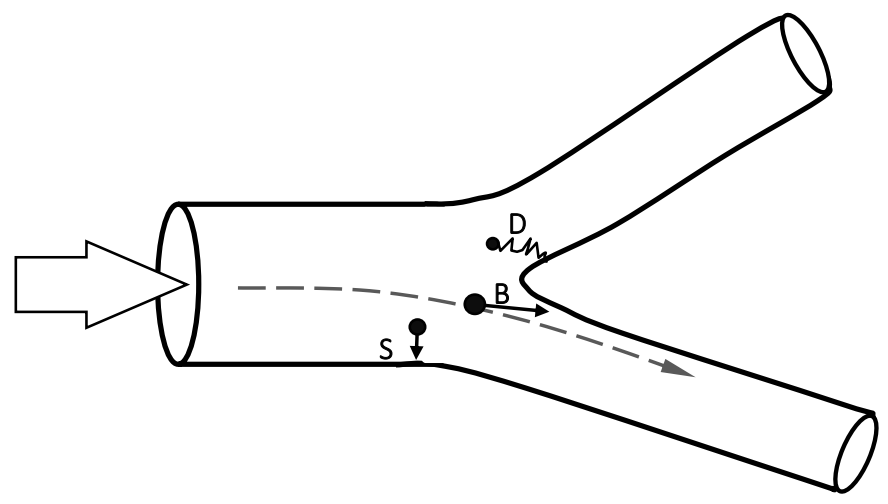

Rysunek 2. Podstawowe mechanizmy depozycji cząstek aerozolowych w układzie oddechowym (na przykładzie rozwidlenia oskrzeli): B - bezwładność, S - sedymentacja, D - dyfuzja brownowska

Figure 2. The basic mechanisms of aerosol particle deposition in the respiratory system (bronchial bifurcation): B - inertia, S - sedimentation, D - Brownian diffusion

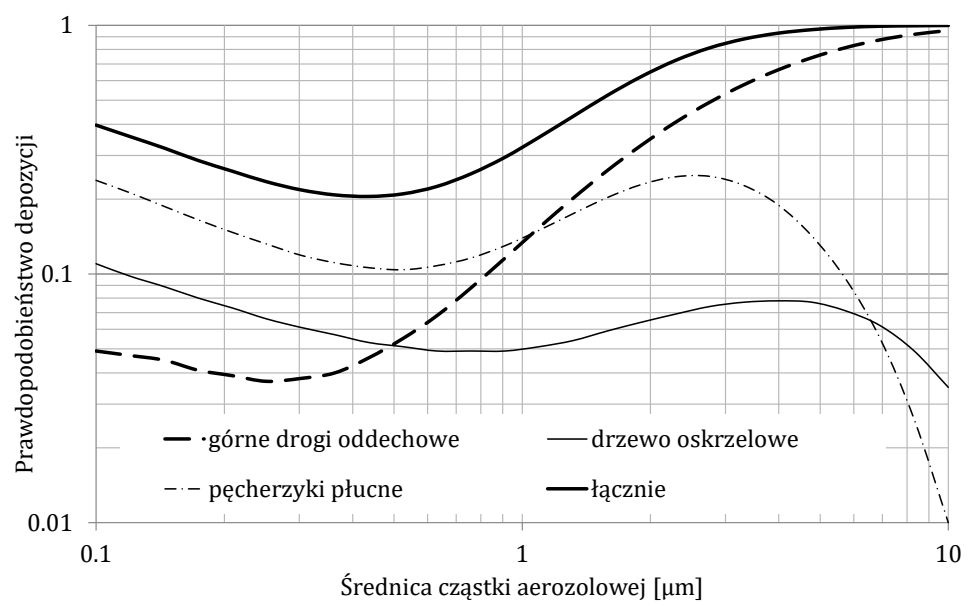

Rysunek 3. Poglądowa zależność prawdopodobieństwa tj. sprawności depozycji cząstek aerozolowych w poszczególnych obszarach układu oddechowego. Pożądanym obszarem depozycji leku są drzewo oskrzelowe i pęcherzyki płucne

Figure 3. The illustrative relationship of the probability (efficiency) of aerosol particle deposition in different regions of the respiratory system. Inhaled drugs should be deposited in the bronchial tree and alveoli 
Biorąc pod uwagę wszystkie aspekty przepływu i depozycji cząstek aerozolowych w UO należy także uwzględnić złożoność czasowo-przestrzenną tego procesu. Wpływ zmienności przepływu aerozolu na depozycję cząstek w rozwidleniach oskrzeli oraz w obszarze usta-gardło-krtań był analizowany $\mathrm{w}$ obliczeniach $\mathrm{i}$ doświadczeniach in vitro wykonywanych na Politechnice Warszawskiej [m.in. 8-10]. Wyniki tych badań pokazały znaczące różnice w stosunku do danych, jakie są uzyskiwane przy typowo zakładanym uproszczeniu w postaci przepływu ustalonego. Różnice te są spowodowane zjawiskami towarzyszącymi zarówno zmianom natężenia przepływu w czasie wdechu, jak i nagłym odwróceniem zwrotu ruchu cząstek w chwili rozpoczęcia wydechu. $\mathrm{Na}$ depozycję w UO wpływają również inne właściwości aerozolu, m.in. kształt cząstek, ich gęstość i higroskopijność, oraz temperatura i wilgotność fazy gazowej (powietrza). Po wejściu do układu oddechowego przez usta lub nos, aerozol kontaktuje się ze środowiskiem o temperaturze bliskiej $37^{\circ} \mathrm{C}$ oraz o wilgotności nasycenia, $\varphi=100 \%$, i już na krótkim obszarze od wlotu, tj. jeszcze w górnych drogach oddechowych, stan termodynamiczny aerozolu stabilizuje się. W przypadku cząstek lub kropel o charakterze hydrofilowym, następuje wzrost ich rozmiarów na skutek kondensacji pary wodnej. Może dochodzić także do wzajemnego oddziaływania cząstek (lub kropel), prowadzącego do ich koagulacji (lub koalescencji). Proces ten jest obserwowany zarówno przy inhalacji aerozoli leczniczych, jak i przy wdychaniu innych stężonych aerozoli, np. dymu papierosowego lub mgły wytwarzanej w elektronicznych papierosach [11]. Innym ważnym efektem występującym w przypadku wdychania stężonych pyłów, dymów lub mgieł, jest tzw. colligative motion, tj. grupowy przepływ chmury cząstek, który ma inną dynamikę niż ruch izolowanych cząstek aerozolowych. Może to wpływać m.in. na sprawność depozycji cząstek.

Zasygnalizowane powyżej zjawiska potwierdzają, że procesy przepływu i osadzania się inhalowanych cząstek w płucach obejmują szereg interesujących zagadnień z zakresu dynamiki układów koloidalnych, jakimi są aerozole. Dodatkowe zagadnienia, związane bezpośrednio $\mathrm{z}$ inhalacyjnym dostarczaniem leków, zostaną przedstawione w dalszej części pracy.

\section{METODY I URZĄDZENIA DO WYTWARZANIA AEROZOLI INHALACYJNYCH}

Aerozole medyczne są wytwarzane w inhalatorach, które są urządzeniami umożliwiającymi powstanie aerozolu w chwili bezpośrednio poprzedzającej jego inhalację. Wymóg ten jest oczywisty, gdyż aerozol jest układem termodynamicznie nietrwałym, ulegającym spontanicznie procesom, które prowadzą do jego zaniku, m.in. w wyniku dyfuzji, odparowania, koagulacji czy sedymentacji. Metoda 
wytwarzania cząstek lub kropel aerozolu zależy od pierwotnej formy leku (roztwór, zawiesina, proszek), stąd wyróżniamy:

1. nebulizatory i inhalatory tzw. miękkiej mgły (SMI - soft mist inhalers) - do rozpraszania leków w postaci ciekłej;

2. inhalatory proszkowe (tzw. DPI - dry powder inhalers) - do rozpraszania leków w postaci sproszkowanej;

3. inhalatory ciśnieniowe (tzw. pMDI - pressurized metered dose inhalers), rozpraszające leki przygotowane $\mathrm{w}$ formie roztworów lub zawiesin substancji leczniczej w skroplonym niskowrzącym propelencie.

Ze względu na zastosowany sposób atomizacji cieczy, nebulizatory dzielimy na pneumatyczne (zasilane sprężonym powietrzem) i ultradźwiękowe, te ostatnie zaś - na klasyczne i siateczkowe (typu mesh, inaczej: membranowe). Wszystkie inhalatory, poza nebulizatorami, są urządzeniami dawkującymi, tj. wyzwalają zadaną porcję leku podczas pojedynczej inhalacji. Porcja ta może występować w postaci wstępnie odważonej, np. jako proszek zawarty wewnątrz kapsułki, lub może być na bieżąco odmierzana w trakcie działania inhalatora (co stanowi osobne wyzwanie inżynierskie). Warto jednak zauważyć, że w odróżnieniu od innych metod wprowadzania leków, np. w formie zastrzyku czy połykanej tabletki, w inhalacjach leczniczych nie możemy zbyt precyzyjnie określić dawki leku dostarczonego do organizmu. Jest to skutkiem zastosowania układu koloidalnego jako nośnika leku. Jak wiadomo, do dolnych dróg oddechowych docierają głównie cząstki o średnicy aerodynamicznej mniejszej niż $5 \mu \mathrm{m}$, więc jeśli w inhalatorze są wytwarzane także większe cząstki, nie utworzą one dawki terapeutycznej (osadzą się głównie w górnych drogach oddechowych). Jednak nawet w przypadku emisji i inhalacji cząstek wyłącznie z pożądanego zakresu rozmiarów, nie wszystkie takie cząstki zostaną zatrzymane w płucach. Jak wskazuje wykres sprawności depozycji (Rys. 3), część inhalowanego aerozolu jest zawsze wydychana (łatwo to można stwierdzić wizualnie np. przy inhalacji dymu papierosowego lub mgły z papierosów elektronicznych). Brak precyzyjnego dawkowania aerozolu leczniczego wynika także z faktu, że zwykle pewna część leku wcale nie opuszcza inhalatora, bo nie ulega aerozolizacji lub jest zatrzymywana, np. w ustniku. W przypadku nebulizatorów występuje tzw. objętość rezydualna RV, która jest definiowana jako objętość cieczy pozostającej na dnie naczynia nebulizacyjnego po zakończeniu inhalacji. Wartość RV waha się od paruset mikrolitrów w tzw. nebulizatorach siateczkowych, do około 1-2 $\mathrm{ml}$ w nebulizatorach pneumatycznych, i stanowi ona część straconej dawki leku ze względu na brak technicznej możliwości jego rozpylenia. Kolejny czynnik odpowiedzialny za straty leków rozpraszanych $\mathrm{w}$ wielu nebulizatorach wiąże się $\mathrm{z}$ tym, że wytwarzają one aerozol w sposób ciągły, zaś do UO jest wprowadzony jedynie aerozol leczniczy powstający podczas 
wdechu. Pozostała porcja aerozolu, powstająca podczas pauzy oddechowej i wydechu, jest emitowana poza układ nebulizator-pacjent, a więc nie ma działania leczniczego.

W przypadku inhalatorów ciśnieniowych pMDI, na straty dawki inhalowanej do płuc wpływają zwykle błędy synchronizacji wdechu z wyzwoleniem chmury aerozolu, tj. z naciśnięciem pojemnika, zaś dodatkowo - także wysoka depozycja bezwładnościowa cząstek $\mathrm{w}$ gardle, wynikająca $\mathrm{z}$ ich dużej prędkości [12]. Warto nadmienić, że zarówno w przypadku nebulizatorów jak i inhalatorów pMDI, wprowadzane są pewne modyfikacje techniczne zmniejszające omówione straty leku [5].

W inhalatorach proszkowych, stopień rozproszenia cząstek aerozolu wprowadzanego do dróg oddechowych jest silnie uzależniony od sposobu inhalacji, gdyż proszek jest porywany i rozpraszany wewnątrz DPI dzięki energii wdechu. $\mathrm{Na}$ proces aerozolizacji wpływają także oddziaływania adhezyjne występujące między cząstkami proszku, m.in. oddziaływania van der Waalsa, elektrostatyczne i pochodzące od bezpośredniego zaczepienia mechanicznego (tzw. interlocking). Zależą one od właściwości materiału proszku oraz struktury wnętrza i powierzchni cząstek (m.in. porowatości i chropowatości), na którą wpływa m.in. sposób wytwarzania/przygotowania proszku. $\mathrm{Na}$ agregację cząstek proszku wpływa dodatkowo wilgotność powietrza, która odpowiada za ewentualną kondensację pary wodnej i spajanie cząstek za pośrednictwem mostków cieczowych [5].

Stopień aerozolizacji proszku zależy od konfiguracji przepływu powietrza przez układ rozpraszania, tzn. od przestrzennego rozkładu naprężeń aerodynamicznych, umożliwiających transfer energii kinetycznej do agregatów cząstek, niezbędny dla ich rozpadu [13]. Dlatego zastosowanie znajdują tutaj różnorodne układy wymuszające lokalne przyspieszenie i turbulizację strumienia powietrza [14,15], choć ich wprowadzenie zawsze wiąże się z podwyższonym spadkiem ciśnienia $\mathrm{w}$ inhalatorze. $\mathrm{W}$ związku ze stratami ciśnienia wewnątrz inhalatorów proszkowych, można je podzielić na nisko-, średnioi wysokooporowe, zaś parametrem liczbowo określającym wewnętrzny opór aerodynamiczny inhalatora DPI jest współczynnik $R_{D}$, zdefiniowany jako:

$$
R_{D}=\frac{\sqrt{\Delta P}}{Q}
$$

gdzie $\Delta P$ jest spadkiem ciśnienia (zwyczajowo podawanym w [hPa]) występującym przy objętościowym strumieniu powietrza $Q$ (zwykle wyrażanym w $\left[\mathrm{dm}^{3} / \mathrm{min}\right]$ ) przepływającego przez inhalator. Dla większości inhalatorów proszkowych $R_{D}$ mieści się $\mathrm{w}$ zakresie $0,05-0,2 \mathrm{hPa}^{0,5} \min \mathrm{dm}^{-3}$. Parametr ten ma duże znaczenie praktyczne, wskazując, które inhalatory - ze względu na zbyt wysoki opór wewnętrzny - nie mogą być poprawnie stosowane przez dzieci, chorych z nasiloną obturacją lub osłabioną sprężystością płuc. 
Z opisanym powyżej sposobem wytwarzania aerozolu w inhalatorach DPI (tzw. pasywnych DPI) wiąże się również problem tzw. przepływo-zależności, tj. zmienności właściwości wytwarzanej chmury aerozolowej (np. wartości uwolnionej dawki, masowego udziału cząstek drobnych, itd.) w funkcji przepływu powietrza. Istnieją inhalatory, w których zmienność ta jest nieznaczna, lecz są także DPI silnie przepływo-zależne, przy czym zmiana jakości aerozolu w funkcji przepływu powietrza nie zawsze jest liniowa, Rys.4. Przepływo-zależność może odpowiadać za gorszą powtarzalność dostarczania leku, jeśli różni chorzy w niejednakowy sposób będą w stanie wdychać powietrze przez dany rodzaj inhalatora. Warto przy tym zwrócić uwagę, że przepływo-zależność nie jest cechą wyłącznie inhalatora DPI, lecz kombinacji inhalator-lek, ponieważ mają na nią wpływ również omawiane wcześniej właściwości fizykochemiczne proszku (m.in. łatwość do deagregacji).

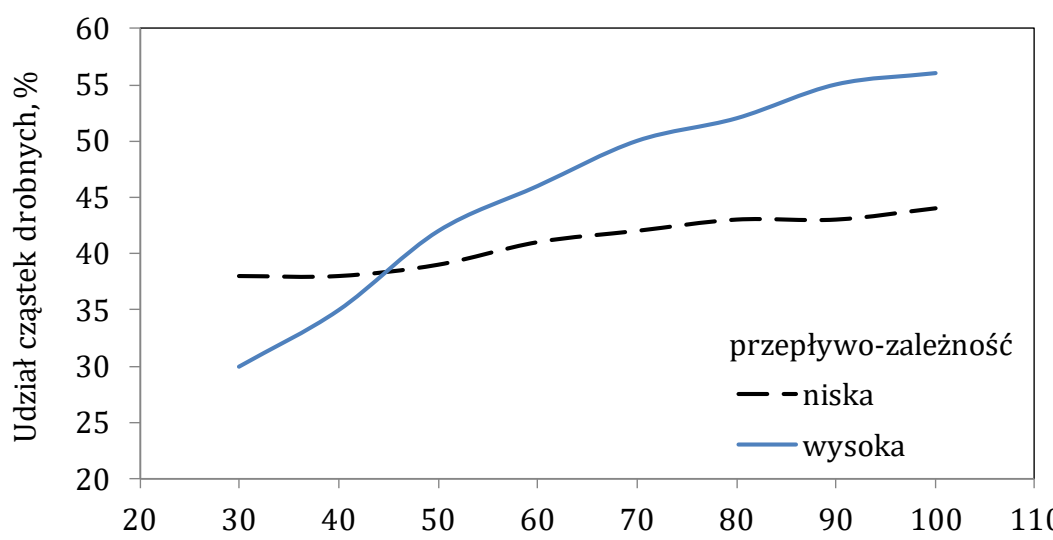

Objętościowy strumień powietrza, $\mathrm{dm}^{3} / \mathrm{min}$

Rysunek 4. Schematyczny wykres niskiej i wysokiej przepływo-zależności inhalatorów DPI: wpływ strumienia powietrza na udział cząstek mniejszych od $5 \mu \mathrm{m}$

Figure 4. Schematic relationships for low and high flow-dependence of DPIs: the influence of airflow rate on the fraction of particles smaller than $5 \mu \mathrm{m}$

Jak już wspomniano, w odróżnieniu od DPI i pMDI, przyjęcie leku aerozolowego przy użyciu nebulizatora wymaga wykonania wielu oddechów, zwykle przez kilka minut. Ta pozorna wada nebulizatorów staje się zaletą w sytuacji, gdy chory nie jest w stanie odpowiednio wykonać manewru oddechowego wymaganego do w pełni poprawnego użycia innych inhalatorów. Dlatego nebulizatory są często stosowane do dostarczania leków osobom starszym i dzieciom, a także podczas wentylacji mechanicznej [16], choć wskazano na pewne 
ograniczenia ich używania np. w leczeniu COVID-19, ze względu na ryzyko emisji wirusa do otoczenia wraz $\mathrm{z}$ aerozolem wydostającym się poza nebulizator $[17,18]$.

\section{PREKURSORY LEKÓW INHALACYJNYCH I CZYNNIKI WPLYWAJĄCE NA JAKOŚĆ AEROZOLU LECZNICZEGO}

W nebulizacji, która - jak już wspomniano - ma szerokie zastosowanie u pacjentów dzieci i pacjentów słabo współpracujących, znaczny wpływ na efektywność terapii inhalacyjnej mają zagadnienia $\mathrm{z}$ zakresu fizykochemii koloidów. Nebulizatory są zalecane do rozpraszania różnorodnych leków w stanie ciekłym, choć na ogół są wstępnie testowane jedynie przy rozpylaniu roztworu soli fizjologicznej lub wodnego roztworu $\mathrm{NaF}$ (wg normy [19]). Leki stosowane w inhalacjach są wodnymi roztworami lub zawiesinami i mogą się różnić pod względem lepkości, napięcia powierzchniowego, przewodnictwa elektrolitycznego oraz innych właściwości fizykochemicznych, mających wpływ na proces ich atomizacji. Znany jest wpływ właściwości reologicznych oraz napięcia powierzchniowego cieczy ( $w$ tym jego wartości dynamicznej, mierzonej w skali milisekund), zarówno na wydajność nebulizacji, jak i na zawartość kropel mniejszych niż $5 \mu \mathrm{m}$, przy czym obserwowane zależności są specyficzne dla określonego rodzaju nebulizatora [20-22]. Na przykład, zawiesin nie udaje się efektywnie rozpylać w klasycznych nebulizatorach ultradźwiękowych [23], z kolei nieniutonowskie właściwości charakteryzujące roztwory kwasu hialuronianowego w obecności chlorku sodu powodują wyraźny spadek wydajności wytwarzania aerozolu w nebulizatorach siateczkowych [24]. Różnice w przewodności elektrolitycznej, wynikające $\mathrm{z}$ różnego stężenia chlorku sodu lub innych elektrolitów, mogą zmieniać sposób działania nebulizatorów siateczkowych, co przypisuje się m.in. kumulacji ładunku elektrycznego przy membranie generującej mgłę [25]. O ile znaczne różnice w lepkości występują tylko w przypadku niektórych leków, to napięcie powierzchniowe rozpylanych farmaceutyków może dość często się różnić ze względu na właściwości powierzchniowo czynne substancji leczniczej lub użytych dodatków (adiuwantów), stosowanych np. jako związki stabilizujące i konserwujące produkt leczniczy.

Dodatkowe kwestie występują w przypadku rozpylania zawiesin leków, np. sterydów. Substancje czynne takie jak budezonid czy propionian flutykazonu są nierozpuszczalne $\mathrm{w}$ wodzie, a więc zawierające je ciekłe preparaty lecznicze są dostępne jako zawiesiny mikrocząstek. Cząstki muszą być odpowiednio małe, aby mogły być przenoszone wewnątrz kropel powstających w nebulizatorze. Jednak cząstki o wielkości mniejszej niż około $3 \mu \mathrm{m}$ - a jest to graniczny rozmiar dla cząstek stałych, aby mogły docierać w głąb UO będąc we wnętrzu kropel powstających w nebulizatorze - nie są stabilne w zawiesinie i szybko agregują, po 
czym ulegają sedymentacji. Stabilność mikrozawiesin można badać typowymi metodami, mierząc m.in. potencjał zeta oraz dynamikę klarowania się cieczy [26]. $\mathrm{W}$ procesie atomizacji, któremu towarzyszą wysokie naprężenia hydrodynamiczne, agregaty cząstek powinny zostać rozbite do cząstek pierwotnych. Jednak nie w każdym nebulizatorze odbywa się to równie skutecznie, a więc można oczekiwać, że w emitowanym i inhalowanym aerozolu będą obecne także krople wcale nie zawierające cząstek sterydu, czyli nie mogące dostarczać leku do UO. Taka sytuacja będzie miała miejsce również w sytuacji, gdy steryd użyty do sporządzenia zawiesiny zawiera zbyt duże cząstki pierwotne (może to dotyczyć niektórych leków odtwórczych, tj. generycznych). Podawanie drogą inhalacyjną leków zawiesinowych napotyka więc na kolejne wyzwania, które należy rozpatrywać na poziomie analizy układów dyspersyjnych. Aby zapobiec nadmiernej agregacji, leki zawiesinowe do nebulizacji są uzupełniane o składniki o charakterze surfaktantów, stabilizujące układ koloidalny. W generykach domieszki te, podobnie jak ich stężenia, nie zawsze są identyczne. Zmieniając w określony sposób napięcie powierzchniowe rozpylanej cieczy, wpływają one jednak na proces atomizacji i wielkość powstających kropel aerozolu. Tym samym istnieje ryzyko, że analogiczne (teoretycznie: w pełni zamienne) leki do nebulizacji nie są równoważne, bo wytwarzany jest $\mathrm{z}$ nich aerozol o innych właściwościach i różnej możliwości docierania do płuc. $Z$ dodatkiem surfaktantów wiąże się dodatkowo efekt pienienia się cieczy $\mathrm{w}$ nebulizatorze, który zmniejsza ilość leku przetwarzanego do formy aerozolu (część leku tworzy pianę i pozostaje na ściankach, zwiększając wartość RV).

Wspomniane zmiany wydajności wytwarzania aerozolu oraz rozkładu średnic kropel spowodowane zróżnicowaniem właściwości fizykochemicznych cieczy, bezpośrednio wpływają na skuteczność terapeutyczną inhalacji. Potwierdza to, że niezwykle ważne staje się precyzyjne rozpoznanie właściwości nie tylko ciekłego prekursora aerozolu, ale i całego układu nebulizator-rozpylana ciecz. Jest to realizowane dzięki zastosowaniu metod pomiarowych umożliwiających wszechstronną charakterystykę właściwości fizykochemicznych leku w stanie ciekłym oraz cech wytwarzanego aerozolu. Jako przykład takich analiz, przedstawiono uzyskaną $w$ niedawnych badaniach [27] zależność rozkładu wielkości kropel dla rozpraszanego hipertonicznego (10\% mas.) roztworu chlorku sodu oraz $0,01 \%$ mas. roztworu surfaktantu Tween 80 (polisorbat 80 - związek stosowany jako adiuwant $\mathrm{w}$ zawiesinach budezonidu), podczas rozpraszania tych cieczy w trzech nebulizatorach: pneumatycznym (Pari LC Sprint) i dwóch membranowych (Intec Twister Mesh i Aerogen Solo), Rys.5. 
(a)

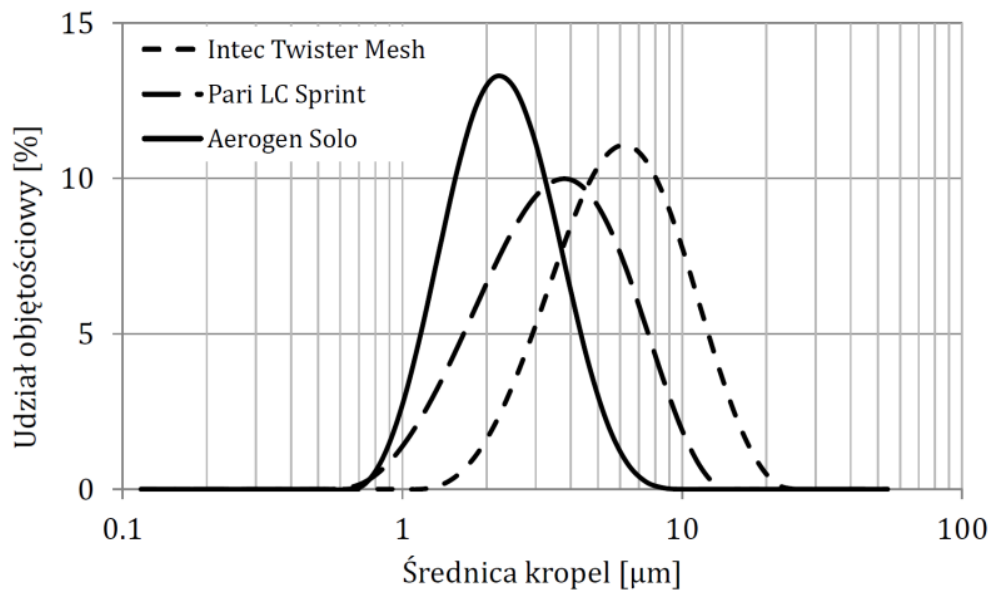

(b)

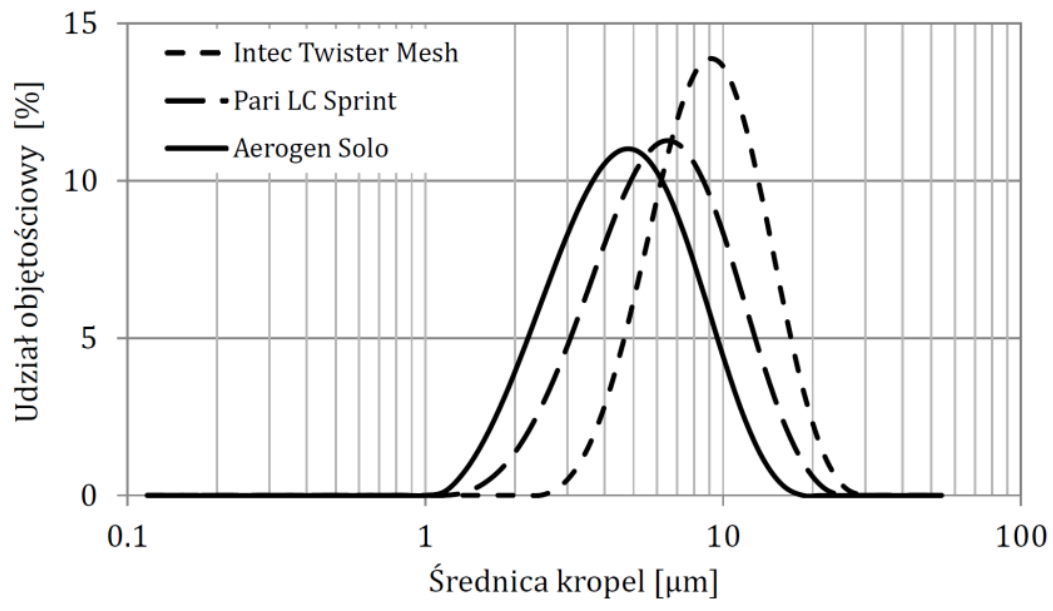

Rysunek 5. Rozkład wielkości kropel wytwarzanych w trzech nebulizatorach $\mathrm{z}$ roztworów wodnych: (a) $10 \%$ mas. $\mathrm{NaCl}$, (b) $0,01 \%$ mas. Tween 80

Figure 5. Droplet size distribution in the aerosol of aqueous solutions atomized in three nebulizers: (a) $10 \% \mathrm{w} / \mathrm{w} \mathrm{NaCl}$, (b) $0.01 \% \mathrm{w} / \mathrm{w} /$ Tween 80

Pomiary wykonano przy użyciu dyfrakcyjnego spektrometru aerozolowego Spraytec (Malvern, Wielka Brytania). Wyniki pokazują, że wielkość kropel aerozolu wyraźnie zależy od zastosowanego nebulizatora (najmniejsze powstają w Aerogen Solo, zaś największe - w Intec Twister Mesh), ale jednocześnie na rozkład ich wielkości wpływają właściwości cieczy. W omawianym przypadku decydujące znaczenie wydaje się mieć napięcie powierzchniowe roztworu: dla $0,01 \%$ mas. roztworu Tween 80 ma ono wartość rzędu $40 \mathrm{mN} / \mathrm{m}$, podczas gdy dla $10 \%$ roztworu $\mathrm{NaCl}$ - około $75 \mathrm{mN} / \mathrm{m}$ [28]. Przytoczone wyniki potwierdzają 
postulowaną wcześniej potrzebę testowania poszczególnych układów leknebulizator, co - w połączeniu $\mathrm{z}$ wiedzą na temat dynamiki przepływu i depozycji aerozolu w układzie oddechowym - pozwoli w lepszym stopniu kontrolować proces leczenia inhalacyjnego.

\section{WYBRANE ASPEKTY ODDZIALYWANIA WDYCHANYCH CZĄSTEK Z POWIERZCHNIĄ PLUC}

Ostatnim aspektem dotyczącym roli fizykochemii koloidów w dostarczaniu leków aerozolowych do płuc, który chcemy zasygnalizować w tej pracy, jest oddziaływanie zdeponowanych cząstek $\mathrm{z}$ powierzchnią układu oddechowego. Nabłonek UO jest pokryty cieczą; w obszarze oskrzelowym jest nią cienka warstwa śluzu, w obszarze pęcherzyków płucnych - płyn wyściółkowy zawierający tzw. surfaktant płucny. Śluz oskrzelowy stanowi szczególny rodzaj bariery chroniącej drogi oddechowe przed wdychanymi substancjami, składający się z lepkiej wierzchniej warstwy żelu zawierającej usieciowane mucyny i inne związki, m.in. thuszcze i DNA [29]), oraz rzadszej warstwy cieczy - zolu (ang. pericilliary fluid), zlokalizowanego od strony urzęsionego nabłonka. Synchroniczny ruch rzęsek przemieszcza wierzchnią warstwę śluzu umożliwiając eliminację osadzonych w niej cząstek pochodzenia aerozolowego przesuwając je w stronę tchawicy i gardła. Opisana struktura śluzu, korzystna dla zabezpieczenia płuc przed wdychanymi zanieczyszczeniami, ogranicza jednocześnie szybkość docierania inhalowanych leków do nabłonka. W kilku pracach badaliśmy wpływ substancji mukolitycznych (rozrzedzających, np. N-acetylocysteiny, NAC - Rys. 6a) na szybkość dyfuzji leku przez warstwę śluzu, postulując celowość opracowania nowego nośnika leków w postaci wieloskładnikowych (kompozytowych) cząstek proszku, zawierających zarówno lek (np. przeciwzapalny, rozkurczający oskrzela, itp.) jak i składnik modyfikujący właściwości śluzu [30] - Rys 6b. Koncepcja ta, jak i metoda wytwarzania cząstek proszku na drodze suszenia rozpyłowego zostały opatentowane [31]. Istotne wyzwanie stanowiło opracowanie sposobu preparatyki cząstek i ich składu, co wynikało z faktu, że dodatek NAC obniżał temperaturę zeszklenia kompozytu, uniemożliwiając wytworzenie proszku o właściwościach pozwalających na jego przyszłe zastosowanie w inhalatorach typu DPI. Kwestie związane $\mathrm{z}$ fizykochemią koloidów pojawiały się więc tutaj na etapie wytwarzania cząstek, ale były także istotne w procesie ich oddziaływania ze śluzem, po drodze obejmując zasygnalizowane już wcześniej zagadnienia aerozolizacji proszku w inhalatorze oraz przepływu i depozycji aerozolu w układzie oddechowym [32]. 
a)

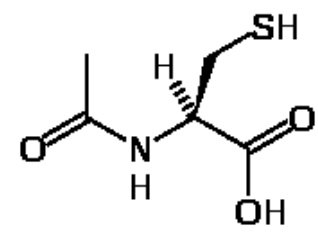

(b)

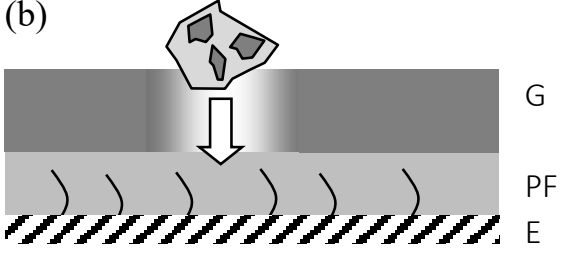

Rysunek 6. (a) budowa cząsteczkowa mukolityku N-acetylocysteiny (CAS 619-91-1); (b) koncepcja działania cząstki kompozytowej uwalniającej mukolityk w celu ułatwienia dyfuzji leku przez warstwę żelu do komórek nabłonka (G -warstwa żelu, PF - warstwa zolu, E - urzęsiony nabłonek)

Figure 6. (a) molecular structure of the mucolytic drug, N-acetylcysteine (CAS 619-91-1); (b) the idea of the activity of composite particle: releasing the mucolytic agent to enhance the diffusion of the other drug through the gel layer to the epithelial cells $(\mathrm{G}-$ gel layer, $\mathrm{PF}$ - pericilliary fluid, E - epithelium with cilia)

Układ surfaktantu płucnego (SP) jest osobnym obiektem szeroko zakrojonych badań fizykochemicznych prowadzonych w wielu ośrodkach na świecie [33-35]. Sama jego struktura, obejmująca aktywną monowarstwę białkowo-lipidową utworzoną na powierzchni faza wodna/powietrze (ALI: air/liquid interface) i poddawaną oscylacji w rytm cyklu oddechowego, jest niezwykle ciekawa z punktu widzenia zjawisk międzyfazowych. Właściwości powierzchniowo-czynne fosfolipidów (głównie DPPC: dipalmitylo-fosfatydylocholiny, jako dominującego składnika SP) sprawiają, że napięcie powierzchniowe cieczy pokrywającej pęcherzyki płucne zmienia się w czasie, wykazując przy tym niejednorodny rozkład przestrzenny. Sprzyja to powstawaniu efektów Marangoniego, tj. przepływów cieczy wywołanych siłami kapilarnymi (ściślej: gradientem napięcia powierzchniowego) [36]. Efekty te mają charakter dynamiczny i wywołują konwekcję warstewki cieczy, przyśpieszając wymianę gazową w płucach, a jednocześnie przemieszczając cząstki osadzone na powierzchni pęcherzyków płucnych [3, 37, 38], Rys. 7.

Wielu badaczy koncentruje się na badaniach podstawowych właściwości ALI zawierającej SP, także w kontekście ich zmian wywoływanych przez wdychane czynniki, które mogą być obecne w środowisku gazowym (m.in. nanocząstki, gazy toksyczne, leki inhalacyjne, itd. [35,39,40]). Pomiary prowadzone są często z wykorzystaniem wagi Langmuira-Wilhelmy'ego, ale także w układach w bardziej realiztycznym stopniu symulujących dynamikę powierzchni ciecz/gaz obecnej w płucach (m.in. tenjsometria pęcherzykowa, oscylującej kropli, itp.). Badania takie pozwalają nie tylko lepiej poznać strukturę i funkcję fizykochemiczną SP jako bariery oddzielającej tkankę układu oddechowego od środowiska gazowego, ale również określić potencjalny wpływ wdychanych substancji na surfaktant, a przez 
to - na stan zdrowia [41-43]. Metody dynamiczne oferują przy tym bardziej czuły sposób analizy zaburzeń funkcji surfaktantu pod wpływem wdychanych aerozoli, w tym także inhalowanych leków. Ostatnie badania pokazują, że nawet jeśli sama substancja farmakologicznie czynna nie wykazuje właściwości powierzchniowo czynnych, to inhalacja nebulizowanych leków może wywoływać zmiany w aktywności SP na skutek obecnych w nich adiuwantów [44]. Wskazuje to na możliwość wystąpienia niepożądanych skutków ubocznych inhalacji niektórych leków w związku z ich bezpośrednim oddziaływaniem na surfaktant płucny.

powietrze

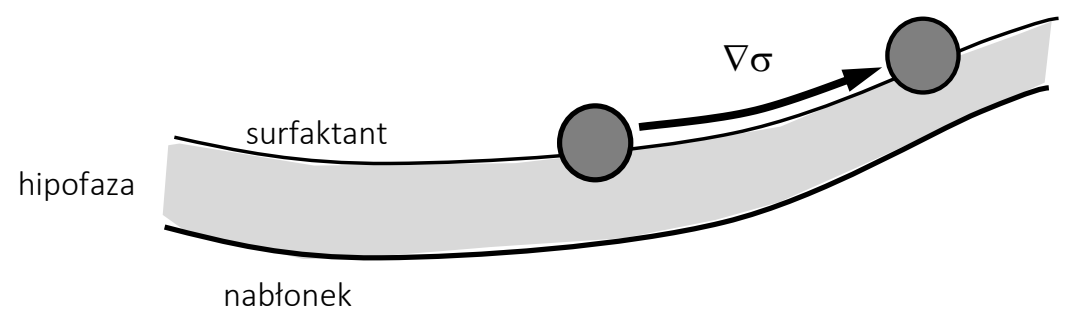

Rysunek 7. Hydrodynamiczny transportu cząstek osadzonych na powierzchni pęcherzyka płucnego pokrytego cieczą (hipofazą) z surfaktantem płucnym. Przepływ cieczy jest spowodowany gradientem napięcia powierzchniowego $\nabla \sigma$

Figure 7. Hydrodynamic transport of particles deposited on the surface of the alveolus covered by the liquid (the hypophase) with the pulmonary surfactant. The liquid flow is driven by the surface tension gradient $\nabla \sigma$

\section{UWAGI KOŃCOWE}

Celem niniejszej pracy było zwrócenie uwagi na znaczenie wybranych zagadnień z zakresu fizykochemii układów koloidalnych dla problematyki związanej z dostarczaniem leków inhalacyjnych oraz z wpływem wdychanych aerozoli na układ oddechowy. Zarówno sam proces wytwarzania aerozolu do celów leczniczych, jak i szereg zjawisk dynamicznych przebiegających w trakcie jego przepływu przez drogi oddechowych, depozycji i oddziaływania z powierzchnią płuc, wymagają rozpoznania procesów specyficznych dla układów dyspersyjnych, ze szczególnym zwróceniem uwagi na zjawiska powierzchniowe. Zagadnienia te są analizowane dzięki wykorzystaniu wiedzy i narzędzi badawczych z obszaru chemii fizycznej i szeroko rozumianej inżynierii chemicznej. Dyscypliny te wydatnie przyczyniają się do opracowywania coraz skuteczniejszych metod dostarczania leków inhalacyjnych i dalszego rozwoju aerozoloterapii. 


\section{PODZIĘKOWANIA}

Część badań, których wyniki zaprezentowano w pracy, została sfinansowana ze środków Narodowego Centrum Nauki, projekt Nr 2018/29/B/ST8/00273 pt. „Procesy atomizacji cieczy dla celowanego wprowadzania leków do układu oddechowego - mechanizmy powstawania, transportu i depozycji kropel”.

\section{PIŚMIENNICTWO CYTOWANE}

[1] O.K. Kurt, J. Zhang, K.E. Pinkerton, Curr. Opin. Pulm. Med., 2016. 22, 138

[2] T.R. Sosnowski Curr. Opin. Coll. Interf. Sci., 2021, 54, 101451.

[3] T.R. Sosnowski Curr. Opin. Coll. Interf. Sci., 2018, 36, 1

[4] A. Emeryk, M. Pirożyński (red.). Polski Przewodnik Inhalacyjny,Via Medica, Gdańsk, 2021.

[5] T.R. Sosnowski, Aerozole wziewne i inhalatory, WIChiP PW, Warszawa, 2012.

[6] T.R. Sosnowski, w: Systemic drug delivery technologies in anti-aging medicines: methods and applications (W.-F. Lai, red.), Springer Nature Switzerland AG, Cham, 2020. Rozdział 12, 327.

[7] European Pharmacopeia Wyd, 9, Council of Europe, Strassbourg, 2017.

[8] A. Moskal, L. Gradoń, J., Aerosol Sci., 2002, 33, 1525

[9] T.R. Sosnowski, A. Moskal, L. Gradoń, Inhalation Toxicol., 2006, 18, 773

[10] A. Moskal, T.R. Sosnowski, Chem. Proc. Eng. 2009, 30, 545.

[11] T.R. Sosnowski, M. Odziomek, Front. Physiol. 2018, 9, 853.

[12] M. Pirożyński, T.R. Sosnowski, Exp. Opin. Drug Deliv. 2016, 13, 1559.

[13] A. Moskal, T.R. Sosnowski, J. Drug Del. Sci. Tech. 2012, 22, 16

[14] J. Gac, T.R. Sosnowski, L. Gradoń, J. Aerosol Sci., 2008, 39, 113.

[15] T.R. Sosnowski, K. Giżyńska, Ł. Żywczyk Ł., Coll. Surf A: Physicochem. Eng. Aspects 2014, 441, 905.

[16] J. Mazela, K. Chmura, M. Kulza, C. Henderson, T.J. Gregory, A. Moskal, T.R. Sosnowski, E. Florek, L. Kramer, M. Keszler, J. Aerosol Med. Pulm. Drug Del., 2014, 27, 58.

[17] A. Emeryk, M. Pirożyński, H. Mazurek, K. Janeczek, T.R. Sosnowski, P. Kuna, Terapia 2020, $4,12$.

[18] T.R. Sosnowski, A. Antonowicz, K. Dobrowolska, w: Chemical and process engineering in environment and health (T.R. Sosnowski i M. Szwast, red.). Wyd. Nauk. ŚBŁ-ITE, Radom, 2020, Rozdział 17, 158.

[19] EN 13544-1:2007+A1:2009 Respiratory therapy equipment — Part 1: Nebulizing systems and their components.

[20] O.N. McCallion, K.M. Taylor, M. Thomas, M., A.J. Pharm. Res. 1995, 12, 1682.

[21] T.R. Sosnowski, J. Bąk, Inż. Ap. Chem. 2010, 49(2), 21

[22] L. Broniarz-Press, T.R, Sosnowski, M. Matuszak, M. Ochowiak, K. Jabłczyńska, Int. J. Pharm. 2015, 485, 41

[23] K. Nikander, M. Turpeinen, P. Wollmer, J. Aerosol Med. 1999, 12, 47.

[24] K. Dobrowolska, T.R. Sosnowski, w: Chemical and process engineering in environment and health (T.R. Sosnowski i M. Szwast, red.). Wyd. Nauk. ŚBŁ-ITE, Radom, 2020, Rozdział $18,166$.

[25] M. Beck-Broichsitter, N. Oesterheld, Eur. J. Pharm. Biopharm. 2017, 119, 11.

[26] T.R. Sosnowski, M. Pirożyński, K. Dobrowolska, Energies, 2021 - zgłoszone do druku

[27] K. Dobrowolska, M. Matyśkiewicz, T.R. Sosnowski, w: 9th EYEC Monograph, WIChiP PW, Warszawa, 2021,152. 
[28] M.A.F. Natsheh, Hebron Univ. Res. J. (A) 2017, 7, 57.

[29] M. Odziomek, M. Kalinowska,A. Płuzińska, A. Rożeń, T.R. Sosnowski, Chem. Proc. Eng. 2017, 38, 217

[30] M. Odziomek, T.R. Sosnowski, L. Gradoń, Int J. Pharm. 2012, 433, 51

[31] L. Gradoń, T. R. Sosnowski, M. Pirożyński, S. Han, “Kompozytowy nośnik leków proszkowych. Sposób wytwarzania nośnika leków oraz urządzenie do wytwarzania cząstki kompozytowej”, Patent nr 220269 (2015) wg zgłoszenia nr 384984 (2008).

[32] M. Odziomek, T.R. Sosnowski. L. Gradoń L. Trans. Porous Media 2015, 106, 439

[33] A.G. Serrano, J. Perez-Gil, Chem. Phys..Lipids, 2006, 141, 105

[34] Y.Y. Zuo, F. Possmayer, J. Appl. Physiol. 2007, 102,1733

[35] E. Guzman, E. Santini, Curr. Opin. Coll. Interf. Sci. 2019, 39, 24

[36] T.R. Sosnowski, Przem. Chem.2006, 85, 1353

[37] T.R. Sosnowski, Efekty dynamiczne w układach ciecz-gaz $\mathrm{z}$ aktywną powierzchnią międzyfazową. OWPW, Warszawa, 2006.

[38] L. Gradoń, A. Podgórski, Chem. Eng. Sci., 1989, 44, 741.

[39] A. Podgórski, T.R. Sosnowski, L. Gradoń, J. Aerosol Med. 2001, 14, 455.

[40] D. Kondej, T.R. Sosnowski, Scientific Reports, 2020, 10, 14044

[41] T.R. Sosnowski, L. Gradoń, A. Podgórski, Aerosol Sci. Techn., 2000, 32, 52.

[42] D. Kondej, T.R. Sosnowski, Env. Sci. Pollut. Res., 2016, 23, 4660

[43] T.R. Sosnowski, K. Jabłczyńska, M. Odziomek, W.K. Schlage, A.K., Kuczaj, Inhalation Toxicol. 2018, 30, 159.

[44] T.R. Sosnowski, K. Dobrowolska, w: Respiratory Drug Delivery 2020 (Dalby R.N. i wsp., red.), Virginia Commonwealth University, Richmond, VA, USA, Tom 3, 737.

Praca wpłynęła do Redakcji 21 maja 2021 r. 
